\title{
The Knowledge Competitiveness of Macedonian Economy - Comparative Analysis
}

\author{
Eftimoski Dimitar, Milenkovski Bozidar
}

\begin{abstract}
When a firm or economy realizes a competitive advantage, actually it possesses something which others lack, and does something which others cannot do, or do not know how to do it. Firms' competitiveness, mostly, stems from knowledge and competency. Basically, it is the accumulation of capital in the form of knowledge, in most of the firms' constitutive systems. Competitiveness determines the productivity level of an economy, whereas the productivity level determines the sustainable prosperity level of an economy. The knowledge economy offers virtually unlimited resources, as human capacity to create is boundless.

Taking into consideration the abovementioned facts, the aim of this paper is to provide responses to the following questions: Why should contemporary firms and economies invest in new knowledge? What is the knowledge competitiveness level of the Macedonian firms and economy? What is the knowledge competitiveness of the Macedonian economy in comparison with the knowledge competitiveness of innovation-driven economies and the remaining efficiency-driven economies?

In order to obtain the answers to these questions, we will make use of some theoretical experiences, supported by a comparative empirical analysis which, in essence, is based on the composite indicators - Knowledge Index and Global Competitiveness Index.
\end{abstract}

Key words: Knowledge, competitiveness, knowledge competitiveness of Macedonian firms and economy, ability to absorb new technologies and knowledge of Macedonian firms, Knowledge Index, Global Competitiveness Index.

\section{INTRODUCTION}

In an economy where the only certainty is uncertainty, the one sure source of sustainable competitive advantage is knowledge (Nonaka, 1991).

Competitiveness determines the productivity level of an economy, whereas the productivity level determines the sustainable prosperity level of an economy. In fact, the productivity level determines the ability of a country to sustain a high level of income. Improved processes and management practices i.e. the new knowledge and technologies, are the main determinants of productivity growth (making better use of available factor of production and resources). Therefore, the national level of competitiveness reflects the extent to which it is able to provide rising quality of life to its citizens.

Contemporary firms which operate in the global surroundings and which are bolstered by the latest information technological devices, most frequently, make use of knowledge as a major means of achieving a competitive advantage ${ }^{1}$. The speed at which knowledge is processed, as well as the speed at which market performance strategies are developed, in compliance with the received information, determine the successfulness of firms' performance.

1. In this respect, firms should distinguish between two types of knowledge: specific and organizational knowledge. The specific knowledge enables a firm to be different from its competitors. This type of knowledge generates a competitive advantage, because it is unique for each firm and it is hard to copy from the competition. The organizational knowledge is a technical type of knowledge concerning operations. It could be in the form of organizational systems and routines (Black \& Boal, 1994). 
Their success is also dependant on employees' readiness for life-long learning and training. From a strategic point of view, the key to firms' corporate success is the development of a unique competitive advantage. However, the building of a competitive advantage is not a means to an end. The foundation for contemporary firms' success is based on building a sustainable competitive advantage. In the long run, a firm acquires a sustainable competitive advantage through its ability to develop a set of core competencies, which will ensure a better approach to satisfying customers/clients' needs in comparison with its competitors ${ }^{2}$.

Therefore, the purpose of this paper is to provide answer to the following questions: Why should contemporary firms and economies invest in new knowledge? What is the knowledge competitiveness level of the Macedonian firms and economy? What is the knowledge competitiveness of the Macedonian economy in comparison with the knowledge competitiveness of innovationdriven economies and the remaining efficiency-driven economies?

\section{THEORETICAL BACKGROUND}

The sources of economic growth of contemporary economies are predominantly based on knowledge-intensive factors. According to the theories of endogenous growth, ideas, knowledge, and human capital are the key determinants of economic growth. The models of endogenous growth have made the surpassing of the so-called 'stagnant theorem' of the classic economic theory possible, and have laid the foundation for the knowledge economy. Paul Romer (1986, 1990), in a series of papers, among which "Increasing Returns and Long-Run Growth" and "Endogenous Technological Change" are the most influential ones, offers an explanation about the sources of technological progress. In fact, in his model of economic growth, he performs endogenization of the technological progress through researchers'efforts aimed at discovering new ideas (knowledge). While according to Romer's model the source of technological progress is research and development, according to Robert Lucas's model, the source of technological progress is human capital (Lucas, 1988).

Huggins and Izushi (2007), states that, at its most fundamental level, the knowledge base of the economy can be defined as the capacity and the capability to create new ideas, thoughts, processes and products, and to translate these into economic value and wealth.

As to economies' competitiveness, Sala-i-Martin et al. (2007) initially define it as a set of institutions, policy and factors which determine the productivity level of a country, explaining that the productivity level determines the sustainable prosperity level one economy can accomplish. Hence, it is highly likely that more competitive economies will tend to accomplish higher income levels for their citizens. Moreover, the productivity level determines the rates of return from investments in economy. Since the speed of economic growth depends on the rates of return, it is clear that the economy which grows faster in the middle and long run is also more competitive. Delgado et al. (2012) define foundational competitiveness as the expected level of output per

2. The core competencies could be defined as collective knowledge within an organization, especially with respect to how various production abilities should be coordinated and how diverse technological flows should be integrated. Namely, this is an accumulative diverse type of knowledge which contributes to achieving competitive success in operations. They are the unique set of abilities which a firm develops in the key areas of its operations (such as, for instance: high quality, services intended for the customers, innovations, team building, flexibility etc.). 
working-age individual that is supported by the overall quality of the country as a place to do business. They use output per potential worker (instead output per current worker - as a measure national productivity) and propose the following three determinants of foundational competitiveness: social infrastructure and political institutions, monetary and fiscal policy and microeconomic environment. Using multiple data sets covering more than 130 countries (2001-2008) they find a positive and separate influence on each determinant on output per potential worker. Furthermore, using their framework, they introduce a new concept "global investment attractiveness", which is defined as the cost of factor inputs relative to a country's competitiveness.

As far as the determinants of competitiveness are concerned, Sala-i-Martin and Artadi (2004) highlight their large number and complexity, reminding of the fact that the classic economic theory, in that respect, first and foremost, was directed towards investments in physical capital, whereas in recent times, the determinants of competitiveness have been more frequently 'looked for' in knowledge, human capital, technological progress, macroeconomic stability etc.

On a firm-level, Huggins and Izushi (2007) underline that, whereas the competitive advantage of firms can arise from size and position within their industry as well as their physical assets, the pattern of competition in advanced economies has increasingly come to favour those firms than can mobilize knowledge and technological skills to create novelty in their products.

Davenport and Prusak (2000) also underline that knowledge could make a sustainable competitive advantage of firms possible, as a result of the fact that it is hard to copy. They explain that competitors, in the course of time, will manage to attain the same quality and price, but the firm which is rich in knowledge and qualitatively manages knowledge, could set a new level of quality and price during the same period of time.

Sum (2010), based on the analysis of data obtained from a survey of 111 responses - majority of human resource professionals - emphasizes that the contemporary firms that operate in the knowledge-based economies become more and more dependent on the skills and knowledge, i.e. absorptive capacity for new knowledge, of their workers. He argues that the knowledge and skills are the most valuable and necessary assets for any firm to complete and generate competitive advantage.

In respect to firms' performances in seven different countries (Austria, France, Germany, Hungary, Spain, Italy and UK), Altomonte et al. (2012), identify firm-level total factor productivity as a major driver of competitiveness. Human capital, $R \& D$ and performance based incentives for employees, are also identified as a triggers of competitiveness.

Finally, when elaborating the importance and role of knowledge assets in determining competitiveness, productivity and output growth, Harris (2011) makes distinction between knowledge that is already internal to the firm (through learning-by-doing that draws on existing knowledge and human capital, build-up though R\&D and similar investments) and knowledge gained externally (through market transactions and spillovers). In this regard, he defines firm's absorptive capacity as its ability to internalize and use external knowledge. Hence, the differences among the firms in levels of absorptive capacity are of particular importance in understanding their competitiveness. 


\section{METHODOLOGY AND DATA}

In order to examine the competitive ability of the Macedonian firms and economy, from the perspective of knowledge accumulation, basically, we use two composite indicators: Knowledge Index (KI) and Global Competitiveness Index (GCI).

KI measures the ability of a country to create, absorb and defuse knowledge. In essence, it indicates the entire potential of a country to develop knowledge. KI is an average of a country's normalized performance scores, expressed with three basic variables: 1) innovations, 2) education, and 3 ) information and communication technologies. KI utilizes a scale from 0 to $10 .^{3}$

GCI is a useful assessment measure of the economic competitiveness of a country ${ }^{4}$. It integrates microeconomic and macroeconomic aspects of competitiveness. This refers to a weighted index, which takes the development stage of the respective country/economy into consideration, as follows: a) First stage: Factor-driven economies (GDP per capita below 2.000 US\$); b) Economies in transition from stage 1 to stage 2 (GDP per capita from 2.000 US $\$$ to 3.000 US\$); c) Second stage: Efficiency-driven economies (GDP per capita from 3.000 US\$ to 9.000 US\$); d) Economies in transition from stage 2 to stage 3 (GDP per capita from 9.000 US\$ to 17.000 US\$) and e) Third stage: Innovation-driven economies (GDP per capita above 17.000 US\$). The index is composed of nine pillars ${ }^{5}$ which are organized in three specific sub-indices ${ }^{6}$. GCI uses a scale from 1 to 7, and the higher the score, the higher the degree of competitiveness of the corresponding economy?

We use the database of The World Bank Institute (WBI) as a source of KI, whereas the rest of the data, mostly derive from The Global Competitiveness Report of The World Economic Forum.

The knowledge competitiveness level of the Macedonian economy, except in the case of the regression analysis, is compared with economies which belong to the second and third stage of development. The group of economies in the second stage of development is made up of: the Czech Republic, Hungary, Bulgaria, Romania and the Slovak Republic, whereas the group of economies in the third stage of development consists of: Finland, Sweden, Germany and Switzerland.

The accumulated level of knowledge (measured in KI), depending on the development stage, is analyzed at two points in time - 1995 and 2009/10, whereas the level of the competitive ability of economies (measured in GCI) - in 2011/2012. GCI trend has been analyzed for the period from 2005/06 to 2011/12.

In order to ascertain the influence of the accumulated knowledge (KI) upon the competitive abilities of the economies (GCI), as well as the influence of the ability for absorption of new

3. For further reference on the structure and calculation of KI see: The World Bank Institute (WBI), Knowledge for Development.

4. The index is a product of the World Economic Forum and its Global Competitiveness Report.

5. 1) Institutions, 2) Infrastructure, 3) Macroeconomic environment, 4) Healthcare and primary education, 5) Higher education and training, 6) Goods market efficiency, 7) Labour market efficiency, 8) Financial market development, 9) Technological readiness, 10) Market size, 11) Business sophistication, 12) Innovation.

6. The sub-indices are linked with the three stages of development of the respective country/economy. The first sub-index is composed of pillars 1-4, the second sub-index is composed of pillars 5-10, the third sub-index consists of pillars 11 and 12 .

7. For further references on the structure, weights and calculation of the GCI, see: The Global Competitiveness Report 2011-2012, World Economic Forum‘. 
knowledge on the part of the employees in the firms (represented by the Quality of the education system of the country - QES) upon the accumulation of new technologies on the part of the firms (represented by the Firm-level technology absorption - FTA), a regressive analysis has been carried out, based on the OLS method, on a cross-sectional data of 34 countries.

Finally, the knowledge competitiveness level of the Macedonian firms is related to the inadequately educated workforce in the firms. To that aim, we have used data from The Global Competitiveness Report, which refer to the most 'problematic' factors to running a business in the country, while, due to the reduction of the number of factors, a weighting procedure has been introduced.

\section{RESULTS}

In this section of the paper, an analysis on the Macedonian firms and economy's competitiveness has been carried out from the aspect of the stock of accumulated knowledge. To that aim, as it was indicated before, two composite indicators have been used - Knowledge Index (KI) and Global Competitiveness Index (GCI).

Following the previously stated logic used in The Global Competitiveness Report of the World Economic Forum, in relation with the classification of economies according to their stage of development, and taking into consideration the fact that Macedonia belongs to the group of economies which are in the second stage of development - efficiency-driven economies, in addition we provide a presentation of an attempt to compare the performances of the knowledge competitiveness of the Macedonian firms and economy with the performances of the knowledge competitiveness of firms and economies which belong to the second and third stage of development. To that end, the average values of KI and GCI have been used for separate groups of economies.

As to the potential of the country to create, absorb and diffuse knowledge, measured in KI, Macedonia is considerably legging behind compared to the average of both efficiency-driven and innovation-driven economies. In the period from 1995 to 2009/10, the Macedonian economy managed to increase its KI by 0.1 index point, whereas in the same period, the economies which belong to the second and third stage of development, on average, managed to increase their KI by 0.21 and 0.19 index points, respectively (Figure 1). 


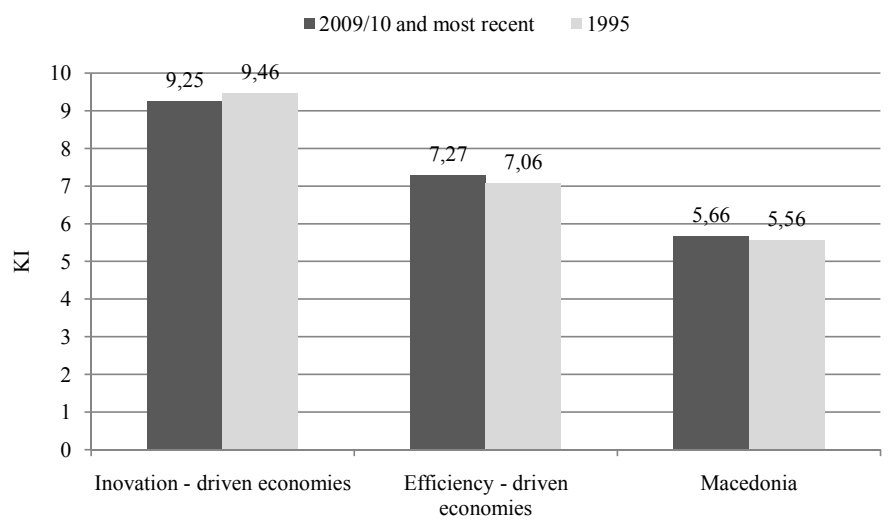

Fig. 1 - KI by the stage of development 2009/2010 and most recent. Source: The World Bank Institute

Bearing in mind the structure of KI, Macedonia marks its greatest legging behind in the 'innovation' variable (4.89 index points below the average of the innovation-driven economies and 2.34 index points below the average of the efficiency-based economies), which reflects a low level of development of the innovative system of the country, which results in a small number of registered patents on the part of both firms and individuals. The 'education' variable marks a growing tendency, first and foremost, owing to the increased rate of enrolment in the secondary and tertiary education, whereas, as far as the decline in the 'information technologies and communications' variable is concerned, no logical conclusion can be drawn (Table 1).

Tab. 1 - KI components by the stage of development (2009/10 and most recent and 1995).

Source: The World Bank Institute

\begin{tabular}{|c|c|c|c|c|c|c|}
\hline \multirow[b]{2}{*}{ Economies } & \multicolumn{2}{|c|}{ Innovation } & \multicolumn{2}{|c|}{ Education } & \multicolumn{2}{|c|}{ ICT } \\
\hline & $\begin{array}{c}2009 / 2010 \\
\text { and most } \\
\text { recent }\end{array}$ & 1995 & $\begin{array}{c}2009 / 2010 \\
\text { and most } \\
\text { recent }\end{array}$ & 1995 & $\begin{array}{c}2009 / 2010 \\
\text { and most } \\
\text { recent }\end{array}$ & 1995 \\
\hline $\begin{array}{l}\text { Innovation } \\
\text { - driven } \\
\text { economies }\end{array}$ & 9.56 & 9.53 & 8.77 & 9.33 & 9.38 & 9.52 \\
\hline Macedonia & 4.67 & 4.43 & 5.42 & 5.23 & 6.88 & 7.00 \\
\hline $\begin{array}{c}\text { Efficiency } \\
\text { - driven } \\
\text { economies }\end{array}$ & 7.01 & 6.80 & 7.47 & 7.19 & 7.33 & 7.19 \\
\hline
\end{tabular}

Theoretically, the growth in the stock of knowledge inevitably leads to an increase in the competitive advantages of contemporary firms and economies. There is a high likelihood that the high values of KI correspond with the high values of GCI (Figure 2). In order to confirm this hypothesis, considering the fact that the correlation in a highly heterogeneous group (economies which belong to different stages of development) could be misleading, we regressed KI on GCI, by using the OLS method on a sample of 34 countries. 


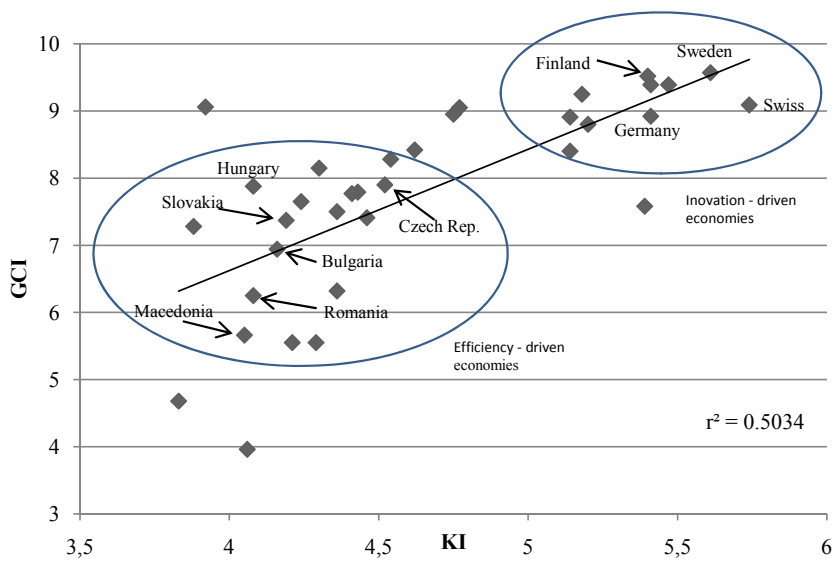

Fig. 2 - GCI and KI (2011/2012 and most recent). Source: The World Bank Institute ant The Global Competitiveness Report 2011-2012, World Economic Forum. Note: KI from 2009/10 and most recent

The results suggest a positive significant correlation between KI and GCI, on the level of $1 \%$, whereas $\mathrm{r}^{2}$ reaches 0.50 . The regression coefficient $\beta$ indicates that KI's growth by 1 index point results in rise in GCI by 0.28 index points (Appendix, Table 2).

Even though Macedonia is still far off from the competitive performances of the innovationbased economies, yet during the past couple of years it exhibits a slight tendency of convergence towards the efficiency-driven economies - in the period from 2005/06 to 2011/2012, GCI grew by 0.79 index points. In the same period, the growth in the average GCI of the innovation-based economies reaches 0.02 index points, whereas the growth in the average GCI of the efficiencydriven economies reaches 0.14 index points (Figure 3).

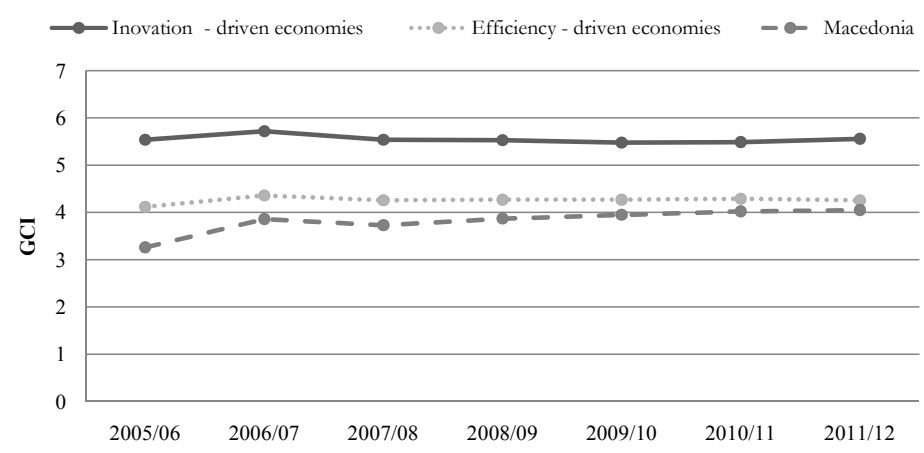

Fig. 3 - GCI trends by the stage of development. Source: The Global Competitiveness Report 2011-2012, World Economic Forum

More precisely, as to the main determinants (pillars) of competitiveness, which stem from GCI, it could be concluded that the Macedonian economy marks certain deficiencies with respect to: 
infrastructure, higher education and training, technological readiness, market size, business sophistication and innovations. As far as the remaining determinants are concerned, the Macedonian economy reaches average values typical of the efficiency-driven economies (Figure 4).

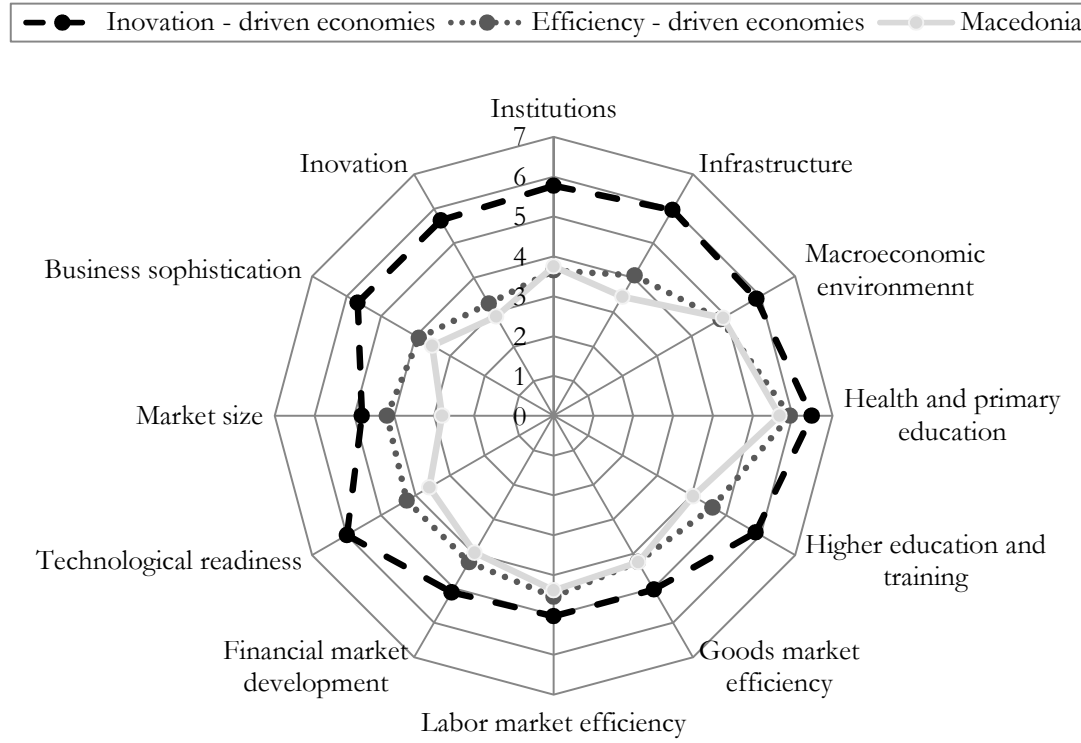

Fig. 4 - GCI components by the stage of development (2011/2012). Source: The Global Competitiveness Report 2011-2012, World Economic Forum

The accumulation of new knowledge and technologies, on the parts of the firms, undoubtedly is directly related to the quality of the education system of the country, as the quality of the education system of the country determines employees' ability for absorption of new knowledge. ${ }^{8}$ In addition, the relation between employees' ability for absorption of new knowledge (presented through the quality of the education system - QES) and firms' capacity for absorption of new technologies (presented through firm-level technology absorption - FTA) have been investigated, upon a sample of 34 countries (Figure 5).

The results of the analysis suggest a positive correlation, significantly different from zero, on a level of $1 \%$. The coefficient of determination shows that approximately $69 \%$ of the total variations in the firms' capacity for absorption of new technologies, could be explained through the quality of the education system of a corresponding country. The regression coefficient $\beta$ indicates that QES growth by 1 index point results in rise in FTA by 0.72 index point. (Appendix, Table 3).

8. The level of human capital acquired during formal education is directly related to the employee's ability to absorb new knowledge in the firm. 


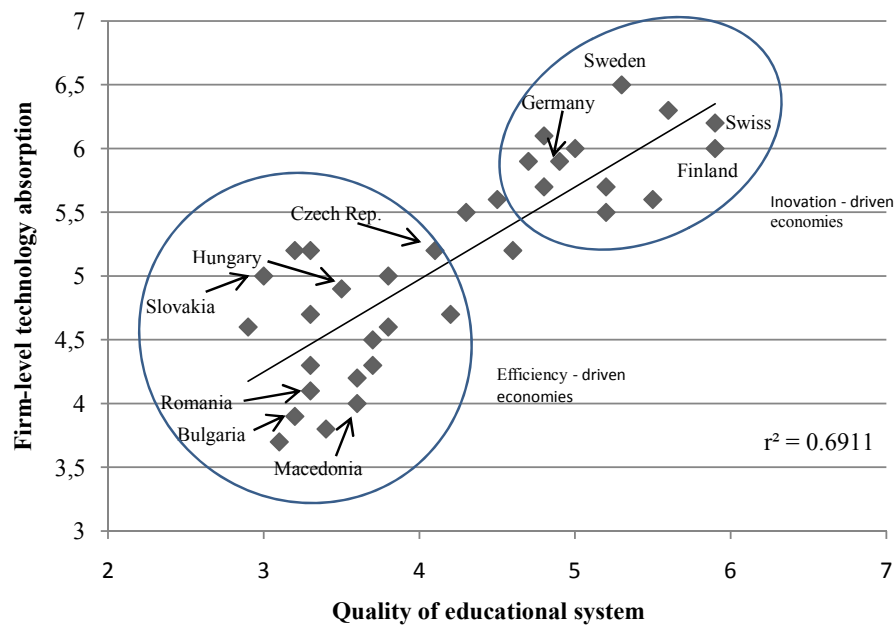

Fig. 5 - Quality of education system and Firms-level technology absorption. Source: The Global Competitiveness Report 2011-2012, World Economic Forum

In fact, this problem (the problem with the ability for absorption of new knowledge and technologies on the part of the Macedonian firms), seems to be one of the most serious problems when it comes to the level of the knowledge competitiveness of the Macedonian firms.

- Firm - level technology absorption (FTA) $\square$ Quality of educational system (QES)

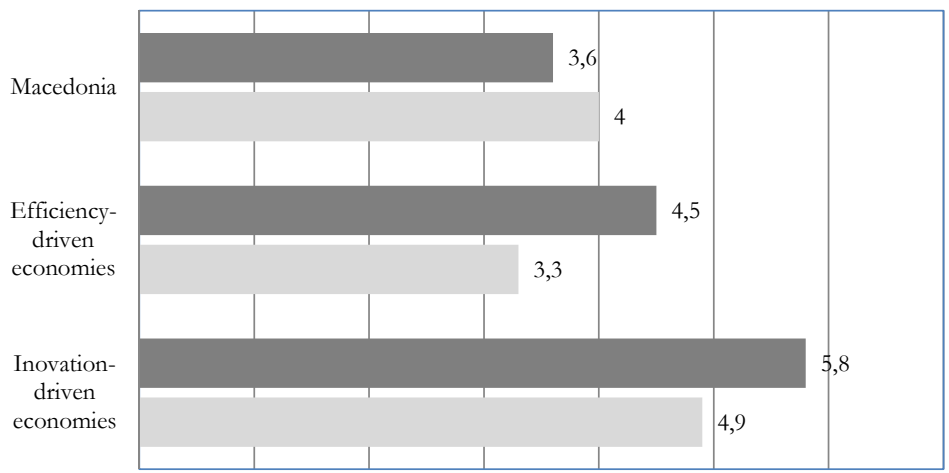

Fig. 6 - Firm-level technology and knowledge absorption by the Stage of development. Source: The Global Competitiveness Report 2011-2012, World Economic Forum

In Macedonia's case, the relations between the new technologies absorption capacity of the firms and new knowledge absorption ability of the employees (presented through the quality of the 
education system), indicates that: 1) Firms' capacity for absorption of new technologies is lower that the ability for absorption of new knowledge on the part of their employees; 2) Firms' capacity for absorption of new technologies exhibits a significant negative deviation from the average of the efficiency-based economies; 3) Employees' ability for absorption of new knowledge is greater than the average of the efficiency-driven economies; 4) Firms and employees' abilities for absorption of new technologies and knowledge is significantly lower than the average of the innovation-driven economies (Figure 6).

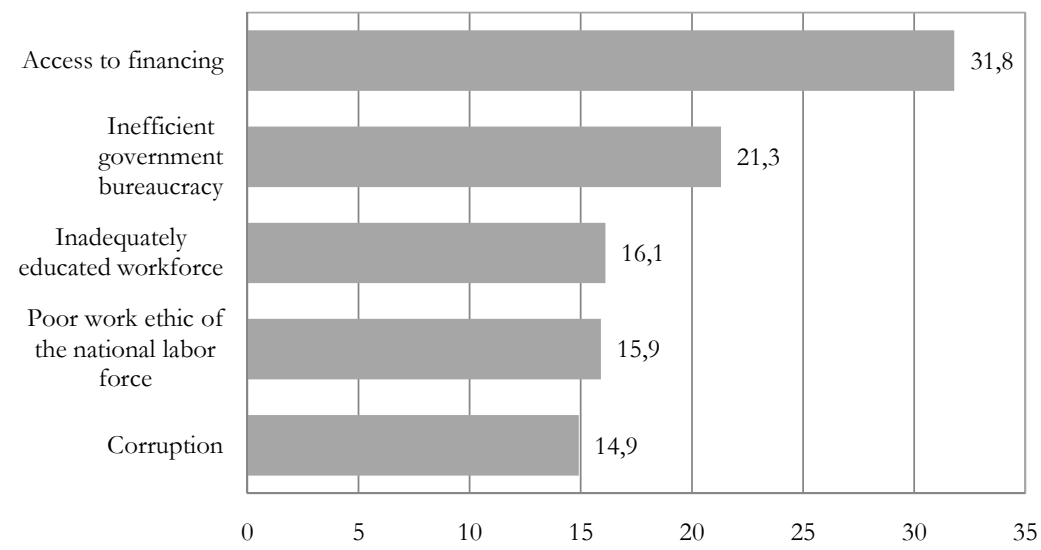

Fig. 7 - The five most problematic factors for doing business in Macedonia (\%). Source: Own calculations based on the Global Competitiveness Report, 2011/12. Note: Data not comparable, due to weighting procedure.

Finally, the level of knowledge competitiveness of the Macedonian firms, apart from the fact that it could be connected to the ability for absorption of new knowledge and technologies, could also be connected with inadequately educated workforce engaged in the firms. Figure 7 , which offers a review of the five 'most problematic' factors to running a business in the country, clearly shows the high share $(16.1 \%)$ of inadequately educated workforce in the Macedonian firms, which is a serious obstacle when it comes to firms' competitiveness.

\section{DISCUSSION AND CONCLUSION}

Competitiveness could be defined as a set of institutions, policies and factors which determine the productivity level of an economy. The productivity level of an economy determines its sustainable prosperity level. Accordingly, more competitive economies tend to achieve higher levels of income for their citizens. The productivity level, also, determines the rates of return on investments in economy. Considering the fact that the speed of the economic growth depends on the rates of return, it turns out that the economy which grows faster in the middle and long run is a more competitive economy. In that context, the determinants of competitiveness, in recent times, can be recognized in: knowledge, human capital, technological process, macroeconomic stability, etc. 
Following the logic of The Global Competitiveness Report, regarding the classification of economies according to their stage of development, Macedonia belongs to the group of economies which are in the second stage of development, efficiency-driven economies.

Taking into consideration the structure (pillars) of GCI, it could be stated that in comparison with the efficiency-based economies, the Macedonian economy displays deficiencies in the following determinants of competitiveness: infrastructure, high education and training, technological readiness, market size, business sophistication and innovations.

GCI trend for the Macedonian economy, for the period from 2005/06 to 2011/12, indicates a slight tendency of convergence towards the efficiency-based economies, and its growth reaches 0.79 index points (which is by 0.77 index points more compared to the growth in the average GCI of the innovation-based economies, and 0.65 index points more that the growth in the average GCI of the efficiency-based economies, for the same period).

As to the competitiveness of the Macedonian economy, observed from the aspect of its potential to create, absorb and diffuse knowledge, it could be stated that for the period from 1995 to $2009 / 10$, the economy shows unsatisfactory results in comparison with both, the innovationbased economies and the remaining efficiency-based economies. Thus, for the period from 1995 to $2009 / 10$, the Macedonian economy managed to increase the knowledge index (KI) by 0.1 index point, which is significantly below the average of the innovation-based economies, but also below the remaining efficiency-based economies ( 0.21 and 0.19 index points, respectively). At the same time, considering the structure of KI, the economy legs behind most in the 'innovation' variable, which results from the small number of registered patents by both firms and individuals. The 'education' variable shows a growing tendency, whereas, regarding the declining tendency of the 'information technologies and communications' variable, no logical explanation can be provided, especially if we take into consideration the continuous growth in the number of users of computer, the Internet and mobile telephones in the analyzed period.

The regression analysis on the influence of the accumulated knowledge (KI) on the competitive capacity of the economy, measured by the Global Competitiveness Index (GCI), based on crosssectional data of 34 countries (composed of countries which belong to the second and the third stage of development, according to 'The Global Competitiveness Report'), showed a significant positive correlation between KI and GCI $\left(\mathrm{r}^{2}=0.50\right)$, and the coefficient $\beta$ suggests that the growth in KI by one index point results in growth in GCI by 0.28 index points.

The regression analysis on the cross-sectional data of 34 countries (composed of countries which belong to the second and third stage of development according to the Global Competitiveness Report), based on the hypothesis that the accumulation of new technologies on the part of the firms (presented through Firm-level technology absorption - FTA) is directly connected to the capacity for absorption of new knowledge on the part of the employees (presented through the Quality of the education system of the country - QES), showed a significant positive correlation between QES and FTA $\left(r^{2}=0.69\right)$, and the coefficient $\beta$ suggests that QES growth by one index point results in FTA growth by 0.72 index points.

In that context, the following conclusions regarding Macedonia can be drawn: 1) The capacity for absorption of new technologies on the part of the firms is lower than the firms' capacity for absorption of new knowledge on the part of their employees; 2) Firms' capacity for absorption of new technolo- 
gies exhibits a significant negative deviation from the average of the efficiency-based economies; 3) The ability for knowledge absorption on the part of the employees in the firms is greater than the average of the efficiency-based economies; 4) Firms and employees' capacity for absorption of new technologies and knowledge is significantly lower than the average of the innovation-based economies.

The level of knowledge competitiveness of the Macedonian firms is associated with the inadequately educated workforce engaged in them. On ranking the five 'most problematic' factors to running a business in the country, it has been acknowledged that the high level $(16.1 \%)$ of the 'inadequately educated workforce' factor in the Macedonian firms, is undoubtedly a very grave problem when it comes to their competitive ability.

Finally, we can conclude that the Macedonia is still far off from the competitive performances of the innovation-based economies, but it exhibits a slight tendency of convergence towards the efficiency-driven economies. In general, in order to enhance its competitiveness level, Macedonia should intensify its efforts in providing new infrastructure, better high education and training, greater technological readiness, business sophistication and more innovations.

\section{References}

1. Altomonte, C., Aquilante, T., \& Ottaviano, G. (2012). The Triggers of Competitiveness, The EFIGE cross-country Report. Retrieved from: http://www.bruegel.org/publications-detail/ view/738/.

2. Black, J. A., \& Boal, K. B. (1994). Strategic resources: Traits, configurations and paths to sustainable competitive advantage. Strategic Management Journal, 15 (Supplement S2), 131-148. http://dx.doi.org/10.1002.smj.4250151009.

3. Davenport, T.,H., \& Prusak, L. (2000). Working knowledge: How Organizations Manage What They Know. Ubiquity, 2000 (August). http://dx.doi.org/10.1145/347634.348775

4. Desai, M., Fukuda, P. S., Johansson, C., \& Sagasti, F. (2002). Measuring the Technology Achievement of Nations and the Capacity to Participate in the Network Age. Journal of Human Development, 3 (1), 95-122. http://dx.doi.org/10.1080/14649880120105399

5. Delgado, M., Ketels, C., Porter, M. E., \& Stern, S. (2012). The Determinants of National Competitiveness. NBER Working Paper Series, Working paper 18249. Retrieved from: http:// www.nber.org/papers/w18249.

6. Doyle, P. (1998). Marketing management and Strategy, London: Prentice-Hall.

7. European Commission. (2011). Innovation Union Competitiveness Report. Brussels: European Commission.

8. Feyrer, J. (2009). Trade and Income: Exploiting Time Series in Geography (NBER Working Papers 14910). Cambridge, MA: National Bureau of Economic Research.

9. Foray, D. (2006). The Economics of Knowledge. Cambridge, MA: MIT Press.

10. Grossman, G. \& Helpman, E. (1991). Innovation and Growth in the World Economy. Cambridge, MA: MIT Press.

11. Harris, R. (2011). Models of Regional Growth: Past, Present and Future. Journal of Economic Surveys, 25 (5), 913-951. http://dx.doi.org/10.1111/j.1467-6419.2010.00630.x

12. Houghton, J., \& Sheehan, P. (2000). A Primer on the Knowledge Economy. Melbourne: Victoria University, Centre for Strategic Economic Studies. 
13. Huggins, R. \& Izushi, H. (2007). The Knowledge Competitiveness of Regional Economies: Conceptualization and Measurement. Bank of Valletta Review, 35, 1-24.

14. Jones, B. A. (1999). Knowledge Capitalism: Business, Work, and Learning in the New Economy, New York: Oxford University Press Inc.

15. Kahin, B., \& Foray, D., (Eds.). (2006). Advancing Knowledge and the Knowledge Economy. Cambridge, MA: MIT Press.

16. Lucas, R. (1988). On the mechanics of economic development. Journal of Monetary Economics, 22 (1), 3-42. http://dx.doi.org/10.1016/0304-3932(88)90168-7

17. Nonaka, I. (1991). The Knowledge - Creating Company. Harvard Business Review, 69, (November - December), 96-104.

18. Porter, M. E. (1990). The Competitive Advantage of Nations. Competitive Intelligence Review, 1 (1), 14. http://dx.doi.org/10.1002/cir.3880010112

19. Porter, M. E. (1998). On Competition. Boston, MA: Harvard Business School Press.

20. Porter, M. E., Delgado, M., Ketels, C., \& Stern, S. (2007). Moving to a New Global Competitiveness Index. The Global Competitiveness Report 2007-2008. World Economic Forum.

21. Romer, P. (1990). Endogenous Technological Change. Journal of Political Economy, 98 (5), 71 102. http://dx.doi.org/10.1086/261725

22. Romer, P. (1986). Increasing Returns and Long-Run Growth. Journal of Political Economy, 94 (5), 1002-1037. http://dx.doi.org/10.1086/261420

23. Sala-i-Martin X., \& Artadi, E.V. (2004). The Global Competitiveness Index. The Global Competitiveness Report 2004-2005. Hampshire: Palgrave Macmillan.

24. Sala-i-Martin X., Blanke, J., Hanouz, D. M., Geiger, T., Mia, I., \& Paua, F. (2007). The Global Competitiveness Index: Measuring the Productive Potentials of Nations (3-50). The Global Competitiveness Report 2007-2008. Hampshire: Palgrave Macmillan.

25. Shami, A. A., Lot, A., Lai, E., \& Coleman, S. (2011). Forecasting Macro-Knowledge Competitiveness; Integrating Panel Data and Computational Intelligence. Retrieved from http://www.forecasters.org/submissions.

26. Sum, V. (2010). The Roll of Training and Firm's Competitiveness in The Knowledge-Based Economy. Review of Business and Technology Research, 3 (1), 1-12.

27. Teece, D. J. (2000). Managing Intellectual Capital. Oxford: Oxford University Press. http:// dx.doi.org/10.1093/0198295421.001.0001

28. World Bank. (2010). Knowledge for development. Tech. Rep. 2009-2010, World Bank. Retrieved from http://econ.worldbank.org.

29. World Economic Forum, The Global Competitiveness Reports from 2005 to 2012. Retrieved from http://www.weforum.org/reports.

\section{Contact information}

Dimitar Eftimoski, Bozidar Milenkouski

St. Kliment Ohridski University, Faculty of Administration and MIS, Department of Economics

Partizanska bb, 7000 Bitola, Macedonia

Email:dimitar@ukim.edu.mk; bozo_mk@yahoo.com

JEL Classification: D83, O57 


\section{Appendix}

Tab. 2 - Regression results of KI versus GCI. Source: Own calculations

\begin{tabular}{|c|c|c|c|c|}
\hline \multicolumn{5}{|c|}{ Dependent Variable: GCI } \\
\hline \multicolumn{5}{|c|}{ Method: Least Squares } \\
\hline \multicolumn{5}{|l|}{ Sample: 134} \\
\hline \multicolumn{5}{|c|}{ Included observations: 34} \\
\hline Variable & Coefficient & Std. Error & $\mathrm{t}$-Statistic & Prob. \\
\hline $\mathrm{C}$ & 2.469226 & 0.386710 & 6.385213 & $(0.0000)$ \\
\hline KI & 0.278763 & 0.048949 & 5.694955 & $(0.0000)$ \\
\hline R-squared & 0.503356 & \multicolumn{2}{|c|}{ Mean dependent var } & 4.635294 \\
\hline Adjusted R-squared & 0.487836 & \multicolumn{2}{|c|}{ S.D. dependent var } & 0.569153 \\
\hline S.E. of regression & 0.407318 & \multicolumn{2}{|c|}{ Akaike info criterion } & 1.098576 \\
\hline Sum squared resid & 5.309045 & \multicolumn{2}{|c|}{ Schwarz criterion } & 1.188362 \\
\hline Log likelihood & -16.67579 & \multirow{2}{*}{\multicolumn{2}{|c|}{$\begin{array}{c}\text { F-statistic } \\
\text { Prob (F-statistic) }\end{array}$}} & 32.43251 \\
\hline Durbin-Watson stat & 1.672650 & & & $(0.000003)$ \\
\hline Jarque-Bera & 0.347865 & \multirow{2}{*}{\multicolumn{2}{|c|}{$\begin{array}{l}\text { White test } \\
\text { Prob. }\end{array}$}} & F stat. $=0.766528$ \\
\hline Prob. & $(0.840353)$ & & & $(0.473229)$ \\
\hline
\end{tabular}

Tab. 3 - Regression results of QES versus FTA. Source: Own calculations

\begin{tabular}{|c|c|c|c|c|}
\hline \multicolumn{5}{|c|}{ Dependent Variable: FTA } \\
\hline \multicolumn{5}{|c|}{ Method: Least Squares } \\
\hline \multicolumn{5}{|l|}{ Sample: 134} \\
\hline \multicolumn{5}{|c|}{ Included observations: 34} \\
\hline \multicolumn{5}{|c|}{ White Heteroskedasticity-Consistent Standard Errors \& Covariance } \\
\hline Variable & Coefficient & Std. Error & t-Statistic & Prob. \\
\hline $\mathrm{C}$ & 2.074029 & 0.403958 & 5.134273 & $(0.0000)$ \\
\hline QES & 0.724916 & 0.087761 & 8.260067 & $(0.0000)$ \\
\hline R-squared & 0.691142 & \multicolumn{2}{|c|}{ Mean dependent var } & 5.105882 \\
\hline Adjusted R-squared & 0.681490 & \multicolumn{2}{|c|}{ S.D. dependent var } & 0.792366 \\
\hline S.E. of regression & 0.447185 & \multicolumn{2}{|c|}{ Akaike info criterion } & 1.285333 \\
\hline Sum squared resid & 6.399178 & \multicolumn{2}{|c|}{ Schwarz criterion } & 1.375119 \\
\hline Log likelihood & -19.85066 & \multirow{2}{*}{\multicolumn{2}{|c|}{$\begin{array}{c}\text { F-statistic } \\
\text { Prob (F-statistic) }\end{array}$}} & 71.60743 \\
\hline Durbin-Watson stat & 2.482047 & & & $(0.000000)$ \\
\hline Jarque-Bera & 1.788952 & \multirow{2}{*}{\multicolumn{2}{|c|}{$\begin{array}{l}\text { White test } \\
\text { Prob. }\end{array}$}} & F stat. $=8.522728$ \\
\hline Prob. & $(0.408852)$ & & & $(0.014103)$ \\
\hline
\end{tabular}

